\title{
Sampler collection gadget for epilithic diatoms
}

\author{
Salomoni, SE. ${ }^{\mathrm{a} *}$, Torgan, $L C{ }^{\mathrm{a} *}$ and Rocha, $O{ }^{\mathrm{b} *}$ \\ ${ }^{a}$ Museu de Ciências Naturais da Fundação Zoobotânica do Rio Grande do Sul - MCN/FZB, \\ Av. Salvador França, 1427, CP 1188, CEP 90690-000, Porto Alegre, RS, Brazil \\ ${ }^{\text {b}}$ Departmento de Ecologia e Biologia Evolutiva da Universidade Federal de São Carlos - UFSCar \\ Via Washington Luis km 235, CP 676, CEP 13565-905, São Carlos, SP, Brazil \\ *e-mail: saiosalomoni@hotmail.com, torgan@cpovo.net, doro@power.ufscar.br \\ Received February 15, 2006 - Accepted May 31, 2006 - Distributed November 30, 2007
}

(With 3 figures)

\begin{abstract}
This work present a new gadget for sampling epilithic diatoms from both lentic and lotic enviroments. The sampler consists of a polystyrene cylinder, left to float on the surface of the water, to which stone substrates are attached. This epilithic diatom sampler (EDS) can be used to detect spatial and temporal richness and density variation in the study of the diatom community, as well as in water quality monitoring.
\end{abstract}

Keywords: sampler collection gadget, epilithic diatoms.

\section{Dispositivo de amostragem para o estudo de diatomáceas epilíticas}

\begin{abstract}
Resumo
Apresenta-se um novo dispositivo para amostragem de diatomáceas epilíticas a ser empregado em ambientes lênticos e lóticos. O amostrador é constituído por cilindro de polietileno flutuante na superfície da água onde são fixados substratos rochosos. Este amostrador de diatomáceas epilíticas (EDS) pode ser usado tanto para detectar variações espaciais e temporais de riqueza e densidade da comunidade de diatomáceas como para o monitoramento da qualidade da água.
\end{abstract}

Palavras-chave: amostrador, diatomáceas epilíticas.

\section{Introduction}

Diatoms are a diverse community of unicellular microalgae encased in a siliceous wall. They have special structures (raphe, stalks, and pads) that benefit substrate adhesion. According to Kelly et al. (1998), diatoms develop faster when they grow on rocks or hard surfaces, in general, cobbles, boulders and pebbles, are used in the sampling of these epilithic flora.

Epilithic diatoms are recognized worldwide as one of the most fitting biological components for water quality assessment, due to their constant presence along the aquatic system, and also because they give a quick response to environmental changes (Lowe and Gale, 1980; Watanabe, 1985; Schoeman and Haworth, 1986; Coste et al., 1991; Pryngiel, 1991; Round, 1991; 1993; Kelly and Whitton, 1995; Descy and Ector, 1999; Whitton and Rott, 1991,1996; Kelly, 2002; Lobo et al., 2002; Lobo et al. 2004; Salomoni, 2004).

Tropical and subtropical aquatic environments usually show fluctuating water levels due to a changing pluviometric regime. When the waters are low, stones in the riverbed and banks become exposed. On the other hand, during the high water season, the same stones stay underwater limiting the development of the diatoms in both situations. For this reason, in these environments, it is common to use artificial substrates like glass or acrylic slides. The glass slides are made of silica, an element that helps diatoms develop, affecting these organisms. Acrylic is an inert element and its smooth surface does not benefit diatom attachment. On the other hand, it makes the development of other algae possible, such as cyanobacteria and filamentous Chlorophyta.

In the specific literature, there is a lengthy discussion about the advantages and disadvantages of using natural or artificial substrates for sampling (Panitz, 1980; Watanabe, 1990; Kelly et al. 1998). The artificial substrates are in general selective and inert and do not show the whole natural community. On the other hand, natural substrates present advantages because the stones supply nutrients that support the community development.

Considering the high value of using rocky substrates and the possibility of them being used all year long in different seasons and hydroperiods, we developed a useful sampler gadget that aims to meet these requirements. 


\subsection{Epilithic Diatom Sampler - EDS}

The epilithic diatom sampler (EDS) is made up of floating polystyrene cylinders, covered with black plastic in order to make them less visible inside the water. Stone substrates (pebbles within 15 and $20 \mathrm{~cm}$ in diameter) are suspended from the cylinders using metal hooks (Figures 1-3), laying below the surface of the water.

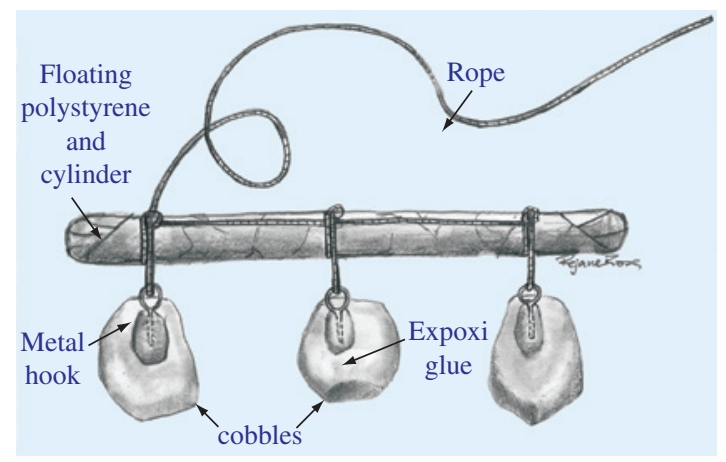

Figure 1. Epilithic diatoms sampler Model EDS.

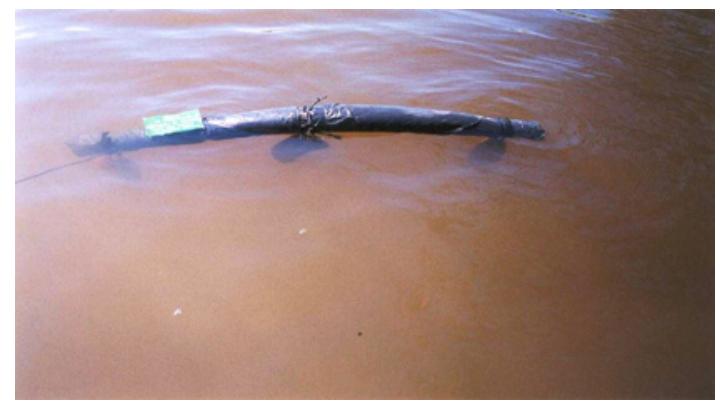

Figure 2. Sampler gadget in Gravataí river, South of Brazil.

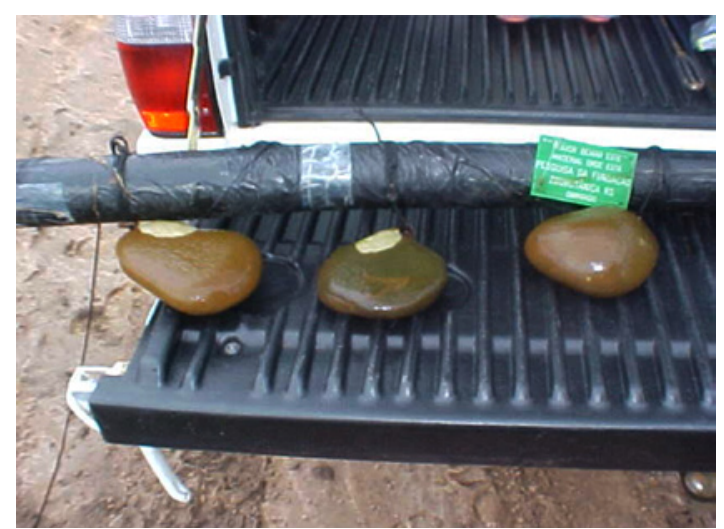

Figure 3. Sampler gadget after the diatom colonization period.
Basaltic cobbles were chosen because they are common in southern Brazilian rivers and also because they have a surface with small porous, making the removal of the attached communities easier.

This gadget is natural and can be located simultaneously in different sampling sites. They can be kept in the environment close to the surface, for longer time spans, since they oscillate with the water level. One probable disadvantage is the use of the gadget in stratified environments where diatoms tend to sediment. In turbulent environments, like Brazilian rivers and lakes where diatoms usually stay on the surface of the water, this gadget offers no limitations.

The EDS was used for the first time in an epilithic diatom study in a low flowing river having satisfactory results (Salomoni, 2004; Salomoni et al., 2006). Recently, it has been used for an epilithic diatom association evaluation, where it was used as a water quality indicator in the Guaiba Lake and it was efficient (Salomoni and Torgan, forthcoming).

Acknowledgments - The authors would like to thank the Fundação de Amparo à Pesquisa do estado do Rio Grande do Sul (FAPERGS), the Conselho Nacional de Desenvolvimento Científico e Tecnológico (CNPq), and the Coordenação de Aperfeiçoamento de Pessoal de Nível Superior (CAPES) for financial support. Moreover, great appreciation is extended to the Museu de Ciências Naturais da Fundação Zoobotânica do Rio Grande do Sul (MCN-FZB) for the infrastructure granted and to Rejane Rosa for drawing the figure of the sampler. To Maria Angélica Oliveira for her critical review of the manuscript, to Rosane Salomoni and to Haywood Dail Laughinghouse IV, for reviewing the English text.

\section{References}

COSTE, M., BOSCA, C. and DAUTA, A., 1991. Use of algae for monitoring rivers in France. p. 75-88. In WHITTON, BA., ROTT, E. and FRIEDRICH, G. (eds.) Use of Algae for Monitoring Rivers. Institut für Botanik, Universität Innsbruck.

DESCY, JP. and ECTOR, L., 1999. Use of diatoms for monitoring rivers in Belgium and Luxemburg. Use of algae for monitoring rivers III (Ed. J. PRYGIEL, WHITTON, BA. and BUKOWSKA, J.), p. 128-137. Agence de l'Eau ArtoisPicardie, Douai.

KELLY, MG. and WHITTON, BA., 1995. The tropic diatom index: a new index for monitoring eutrophication in rivers. Journal of Applied Phycology. vol. 7, p. 433-444.

-, 1998. Biological monitoring of eutrophication in rivers. Hydrobiologia, vol. 384, p. 55-67.

KELLY, MG., 2002. Role of benthic diatoms in the implementation of the Urban Wastewater Treatment Directive in the River Wear, North-East England. Journal of Applied Phycology, vol. 14, p. 9-18.

LOBO, EA., CALLEGARO, VLM. and BENDER, P., 2002. Utilização de algas diatomáceas epilíticas como indicadoras da qualidade da água em rios e arroios da Região Hidrográfica do Guaíba, RS, Brasil. Santa Cruz do Sul: EDUNISC. 127p.

LOBO, EA., CALLEGARO VLM., HERMANY, G. BES, D. WETZEL, CA. and OLIVEIRA, MA., 2004. Use of epilithic 
diatoms as bioindicators from lotic systems in southern Brazil, with special emphasis on eutrophication. Acta Limnol. Bras. vol. 16 , no.1, p. 25-40.

LOWE, RL and GALE, WF., 1980. Monitoring river periphyton with artificial benthic substates. Hydrobiologia, vol. 69, n. 3, p. 235-244.

PANITZ, CMN., 1980. Estudo comparativo do perifiton em diferentes substratos artificiais na represa do LOBO ("BROA"), São Carlos, SP. 224p. (Dissertação de Mestrado) - PPGERNUFSCar, São Carlos, São Paulo.

PRYGIEL, J. 1991. Use of benthic diatoms in surveillance of the Artois-Picardie basin hydrobiological quality. In WHITTON, BA., ROTT, E. and FRIEDRICH, G. (eds), Use of algae for monitoring rivers. E. Rott, Institut für Botanik, Univ. Innsbruck, p. 89-96.

ROUND, FE., 1991. Diatoms in river water-monitoring studies. Journal of Applied Phycology, vol. 3, p. 129-145.

-, 1993. A Review and Methods for the Use of Epilithic Diatoms for Detecting and Monitoring Changes in River Water Quality. HMSO Publisher, London. 63p.

SALOMONI, SE., 2004. Diatomáceas Epilíticas indicadoras da Qualidade de água na Bacia do Rio Gravataí, Rio Grande do Sul, Brasil. 230p. (Tese de Doutorado) - PPGERN- UFSCar, São Carlos, São Paulo.

SALOMONI, SE., ROCHA, O. CALLEGARO, VLM. and LOBO, EA., 2006. Epilithic diatoms as indicators of water quality in Gravataí river, Rio Grande do Sul, Brazil. Hydrobiologia, vol. 559, no.1, p. 233-246.

SCHOEMAN, FR. and HAWORTH, EY., 1986. Diatom as indicator of pollution. Proceedings of the Eighth International Diatoms Symposium 1984. Ricard, M. (ed) Koeltz Scientific Books, Koenigstein. p. 757-766.

WATANABE, T., 1985. Étude de la relation entre le périphyton et la qualité chimique de l'eau des rivières: utilisation de bioessais "in situ" (substrats artificiels) pour caracteriser l'état de pollution des eaux. 127p. (Tese de Doutorado) - Université Paul Sabatier, Toulouse, França.

WATANABE, T., 1990. Perifiton: Comparação de metodologias empregadas para caracterizar o nível de poluição das águas. Acta. Limnol. Brasil. vol. 3, p. 593-615.

WHITTON, BA., ROTT, E. and FRIEDRICH, G., 1991. (Eds.) Use of algae for monitoring rivers. In Proc. International Symposium 26-28 May 1991, Germany, 183p.

WHITTON, BA. and ROTT, E., 1996. (Eds.) Use of algae for monitoring rivers II. In Proc. II International Symposium. 17-19, September 1995, Innsbruck, Austria, 196p. 